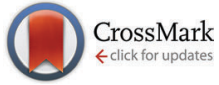

Cite this: New J. Chem., 2015 39, 1619

Received (in Montpellier, France) 11th August 2014, Accepted 8th October 2014

DOI: 10.1039/c4nj01351d

www.rsc.org/njc

\section{Energetic alliance of tetrazole-1-oxides and 1,2,5-oxadiazoles $\dagger+$}

\author{
Dennis Fischer, Thomas M. Klapötke, * Marius Reymann, Jörg Stierstorfer and \\ Dennis Fischer, Thor
Maurus B. R. Völkl
}

\begin{abstract}
The connection of highly endothermic heterocycles with high nitrogen as well as oxygen content is a recent trend in the development of new energetic materials in order to increase densities and stabilities. Bis(1-hydroxytetrazolyl)furazane (9) and bis(1-hydroxytetrazolyl)furoxane (10) were synthesized for the first time from dicyanofurazane and dicyanofuroxane, respectively. Several nitrogen-rich compounds (e.g. ammonium and hydroxylammonium) and metal salts thereof were prepared. Most compounds were characterized by single crystal X-ray diffraction. In addition all compounds were analyzed by vibrational spectroscopy (IR and Raman), multinuclear NMR spectroscopy, elemental analysis and DSC measurements. The heats of formation of 4, 5, 15-16, 20 and 24 were calculated using the atomization method based on CBS-4M enthalpies. With these values and the experimental (X-ray) densities several detonation parameters such as the detonation pressure, velocity, energy and temperature were computed using the EXPLO5 code (V.5.05). In addition, the sensitivities towards impact, friction and electrical discharge were tested using the BAM drop hammer and friction tester as well as a small scale electrical discharge

device.
\end{abstract}

\section{Introduction}

Research towards insensitive replacements for hexogen (RDX), octogen (HMX) and nitropenta (PETN) is still of particular interest in our and many other research groups worldwide. RDX has been identified as toxic and possibly carcinogenic. ${ }^{1}$ Several attempts to synthesize appropriate replacements for RDX have been made in the recent past using tetrazole oxides. ${ }^{2-4}$ The purpose of this study was to combine furazanes (1,2,5-oxadiazoles) and furoxanes (1,2,5-oxadiazole-2-oxides) with tetrazole oxides. The connection of highly endothermic heterocycles with high nitrogen as well as oxygen content is a recent trend in the development of new energetic materials in order to obtain powerful materials with great density and appropriate oxygen balance on the one hand, and perfect stability on the other hand. Tetrazoles (without N-oxide) have already been attached to furazanes ${ }^{5}$ and furoxanes. ${ }^{6}$ The resulting literature known compounds $\mathbf{2 4}$ and $\mathbf{2 5}$ as well as the new ones $\mathbf{9}$ and $\mathbf{1 0}$ are displayed in Fig. 1.

Various nitrogen rich salts of $\mathbf{9}$ and $\mathbf{1 0}$ as well as metal salts were synthesized to investigate their properties as potential

Ludwig Maximilians University of Munich, Department of Chemistry,

Energetic Materials Research, Butenandtstr. 5-13, D-81377 Munich, Germany.

E-mail:tmk@cup.uni-muenchen.de

$\dagger$ Dedicated to Dr. Klaus Römer on the occasion of his 75th birthday.

\# Electronic supplementary information (ESI) available: X-ray diffraction data, computations, and general experimental methods. CCDC 988403-988414. For ESI and crystallographic data in CIF or other electronic format see DOI: 10.1039/c4nj01351d

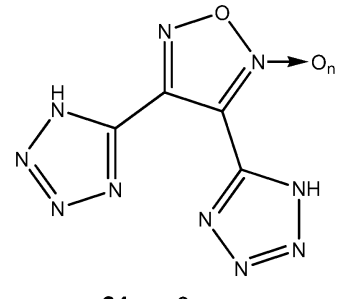

$24 n=0$

$25 n=1$

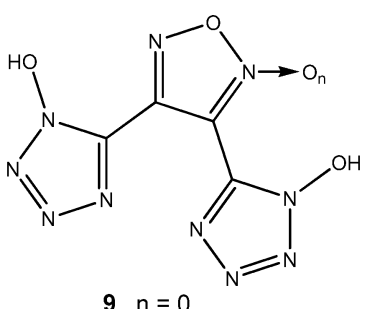

$10 n=1$
Fig. 1 Compounds 9 and 10 and the literature known compounds $24^{5}$ and $25{ }^{6}$

energetic ingredients. The resulting 3,4-(1-oxidotetrazolyl)furoxanes and furazanes are capable and fairly stable compounds in their deprotonated form.

\section{Results and discussion}

\section{Synthesis}

Compounds $\mathbf{9}$ and $\mathbf{1 0}$ were synthesised using a similar protocol from dicyanofurazane ${ }^{7}$ and dicyanofuroxane ${ }^{8}$ as depicted in Scheme 1.

Hydroximoylamines $\mathbf{3}$ and $\mathbf{4}$ are made from the nitriles by exothermic addition of aqueous hydroxylamine in ethanol in about $85 \%$ yield. Hydroximoyl chlorides 5 and $\mathbf{6}$ were synthesized from 3 and 4 by diazotization in $15 \% \mathrm{HCl}$ and subsequently 


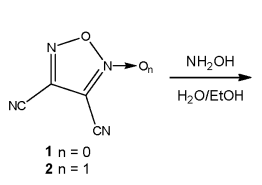

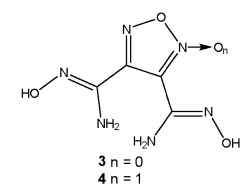<smiles></smiles><smiles></smiles>

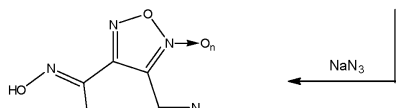
$9 n=0$
$10 n=1$

$$
\begin{aligned}
& 7 n=0 \\
& 8 n=1
\end{aligned}
$$

Scheme 1 Synthetic protocol for 9 and 10.

extracted into diethyl ether. The reaction of $\mathbf{5}$ and $\mathbf{6}$ with sodium azide in aqueous ethanol affords hydroximoylazides 7 and $\mathbf{8}$, respectively, which are also extracted into diethyl ether. The dried ether phase was saturated with gaseous $\mathrm{HCl}$ at $0{ }^{\circ} \mathrm{C}$ and stirred for $24 \mathrm{~h}$ in order to close the desired aromatic tetrazole-oxide rings. Compounds $\mathbf{9}$ and $\mathbf{1 0}$ are obtained as slightly yellow sticky oils after removal of the ethereal $\mathrm{HCl}$ solution.

Salts of compounds $\mathbf{9}$ and $\mathbf{1 0}$ could be easily prepared by the addition of a base or the corresponding carbonates/bicarbonates to aqueous solutions of $\mathbf{9}$ and 10. The silver salt of $\mathbf{1 0}$ precipitated upon the addition of aqueous silver nitrate. An overview of the salts prepared in this work is given in Scheme 2.

\section{Crystal structures}

Single crystals for XRD of compounds 3-6, 11, 12, 14-17, 20 and 23 could be obtained during this work. Crystallographic data and parameters as well as CCDC numbers are given in Tables S1 and $\mathrm{S} 2$ in the ESI. $\neq$

In general, all bond lengths and angles were observed as expected and are comparable to similar crystal structures of furazanes, ${ }^{9}$ furoxanes, ${ }^{10}$ and tetrazole-oxides ${ }^{11}$ in the literature. Compound 3 crystallizes in the monoclinic space group $C 2 / c$ with four molecules in the unit cell. The molecular unit is generated by $C_{2}$ symmetry through atom $\mathrm{O} 1$ and bond $\mathrm{C} 1-\mathrm{C} 1^{\mathrm{i}}$. The density $\left(1.667 \mathrm{~g} \mathrm{~cm}^{-3}\right.$ at $\left.100 \mathrm{~K}\right)$ of 3 is significantly smaller than that of the corresponding furazane 7 $\left(1.780 \mathrm{~g} \mathrm{~cm}^{-3}\right.$ at $\left.173 \mathrm{~K}\right)$. Compound $\mathbf{4}$ crystallizes in the monoclinic space group $P 2_{1} / n$. The molecular moieties are depicted in Fig. 2.

Hydroximoyl chlorides 5 and 6 crystallize in the monoclinic $\left(P 2_{1} / n\right)$ and orthorhombic $\left(P 2_{1} 2_{1} 2_{1}\right)$ crystal systems with four molecules in the unit cell. The molecular units are shown in

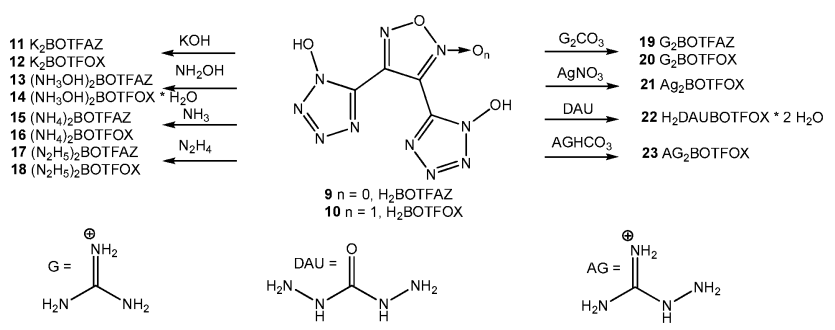

Scheme 2 Synthesis of salts $\mathbf{1 1 - 2 3}$

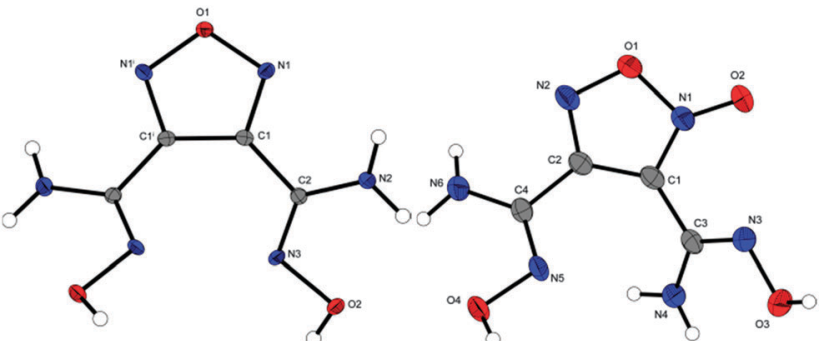

Fig. 2 Molecular moieties of $\mathbf{3}$ and $\mathbf{4}$ thermal ellipsoids are drawn at the $50 \%$ probability level. 3 : Symmetry code: $1-x, y, 1.5-z$. Selected bond lengths (Å): O2-N3 1.4194(18), N3-C2 1.291(2), N2-C2 1.351(2); 4: Selected bond lengths (Å): O2-N1 1.224(2), N4-C3 1.354(3), N4C3 1.354(3), O3-N3 1.418(3).

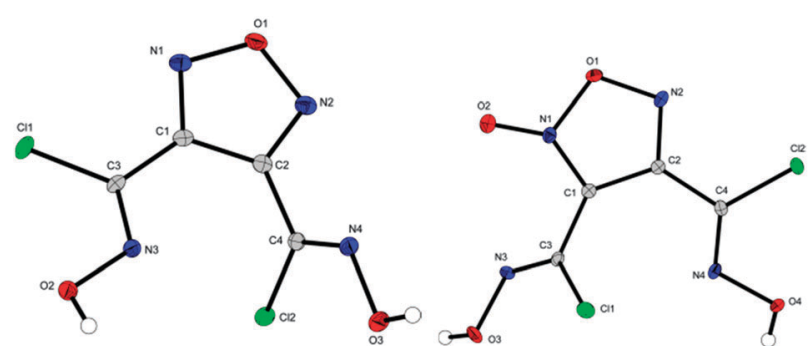

Fig. 3 Molecular moiety of $\mathbf{5}$ and $\mathbf{6}$. Thermal ellipsoids are drawn at the $50 \%$ probability level.
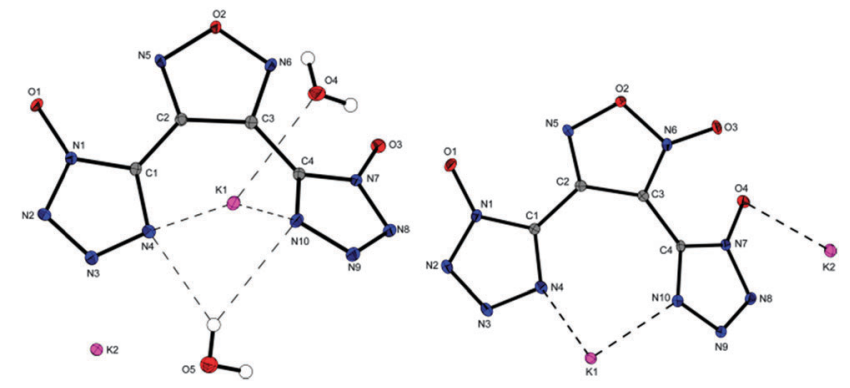

Fig. 4 Molecular moiety of $\mathbf{1 1}$ and 12. Thermal ellipsoids are drawn at the $50 \%$ probability level. Selected bond lengths of 11/12 (Å): O1 N1 1.297(2), N1 N2 1.340(2), N1 C1 1.360(2), N2 N3 1.321(2), N3 N4 1.344(2) O2 N5 1.3822(19), O2 N6 1.430(2), O3 N6 1.2343(19)

Fig. 3. The density of furazane $\left(1.909 \mathrm{~g} \mathrm{~cm}^{-3}\right.$ at $\left.100 \mathrm{~K}\right)$ again is slightly lower than that of furoxane $\left(1.949 \mathrm{~g} \mathrm{~cm}^{-3}\right.$ at $100 \mathrm{~K})$.

Crystal structures of both potassium salts were obtained. The structure of furazane 11, which crystallizes in the monoclinic space group $P 2_{1} / c$, contains two crystal water molecules resulting in a lower density of $1.926 \mathrm{~g} \mathrm{~cm}^{-3}$ (at $100 \mathrm{~K}$ ). For furoxane 12 (triclinic, $P \overline{1}$ ) a density of $2.156 \mathrm{~g} \mathrm{~cm}^{-3}$ at $100 \mathrm{~K}$ has been calculated. In both structures two rings (containing atoms $\mathrm{C} 1$ and $\mathrm{C} 2 / \mathrm{C} 3$ ) are almost in plane while the third one is significantly deviated. Molecular moieties of $\mathbf{1 1}$ and $\mathbf{1 2}$ are depicted in Fig. 4.

Compound $\mathbf{1 4} \cdot \mathrm{H}_{2} \mathrm{O}$ could only be obtained in the crystalline form with inclusion of one crystal water molecule (Fig. 5). 


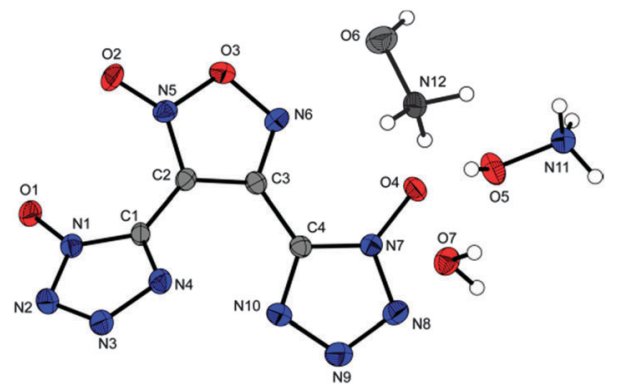

Fig. 5 Molecular moiety of $\mathbf{1 4} \cdot \mathrm{H}_{2} \mathrm{O}$. Thermal ellipsoids are drawn at the $50 \%$ probability level.
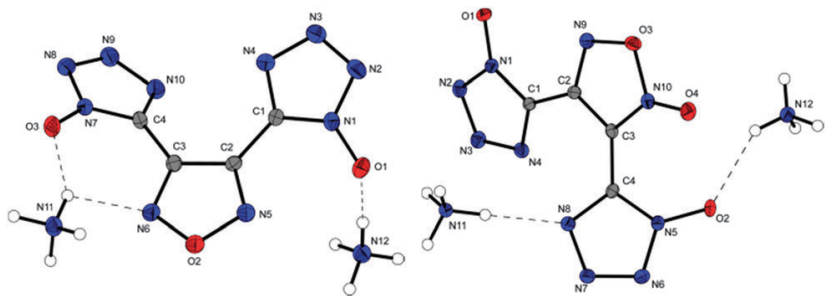

Fig. 6 Molecular moiety of ammonium salts $\mathbf{1 5}$ and $\mathbf{1 6}$. Thermal ellipsoids are drawn at the $50 \%$ probability level. 15: Selected bond lengths (Å): C1-C2 1.455(3), C2-C3 1.432(3), C3-C4 1.457(3), O1-N1 1.327(2), O3-N7 1.327(2); 16: Selected bond lengths (Å): C1-C2 1.450(3), C3-C2 1.423(3), C3-C4 1.449(3), O1-N1 1.3187(19), O2-N5 1.323(2), O4-N10 1.231(2).

It crystallizes in the monoclinic space group $P 2_{1}$ with a density of $1.794 \mathrm{~g} \mathrm{~cm}^{-3}$ at $173 \mathrm{~K}$.

Bisammonium salt 15 crystallizes in the orthorhombic space group $P b c a$ with a calculated density of $1.686 \mathrm{~g} \mathrm{~cm}^{-3}$ at $298 \mathrm{~K}$. The corresponding bisammonium furoxane salt 16 crystallizes with a higher density of $1.748 \mathrm{~g} \mathrm{~cm}^{-3}$ (at $293 \mathrm{~K}$ ) in the monoclinic space group $P 2_{1} / c$. Both structures shown in Fig. 6 are dominated by strong hydrogen bonds involving all $\mathrm{NH}_{4}^{+}$protons.

The products of deprotonation of $\mathbf{9}$ with hydrazine and different guanidinium bases have not been obtained as single crystals. The hydrazinium salt of $\mathbf{9}$ crystallizes in the triclinic $(P \overline{\mathbf{1}})$ crystal system and with a density of $1.727 \mathrm{~g} \mathrm{~cm}^{-3}$ at $236 \mathrm{~K}$ without inclusion of crystal water. The molecular moiety is shown in Fig. 7.

The bisguanidinium salt 20 (Fig. 8) crystallizes in the monoclinic space group $C 2 / c$ and with a density of $1.739 \mathrm{~g} \mathrm{~cm}^{-3}$ at $100 \mathrm{~K}$ (Fig. 8).

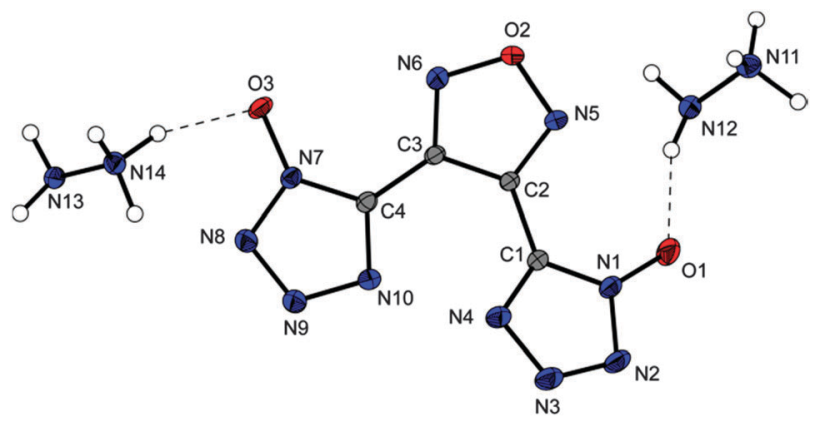

Fig. 7 Molecular moiety of hydrazinium salt 17 . Thermal ellipsoids are drawn at the $50 \%$ probability level.
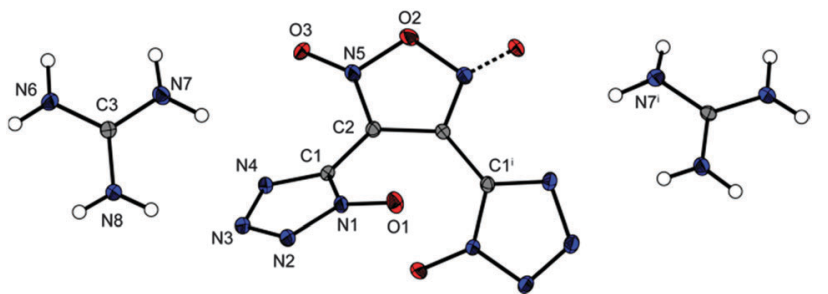

Fig. 8 Molecular moiety of guanidinium salt 20 . Thermal ellipsoids are drawn at the $50 \%$ probability level. Symmetry code: (i) $1-x, y, 0.5-z$.

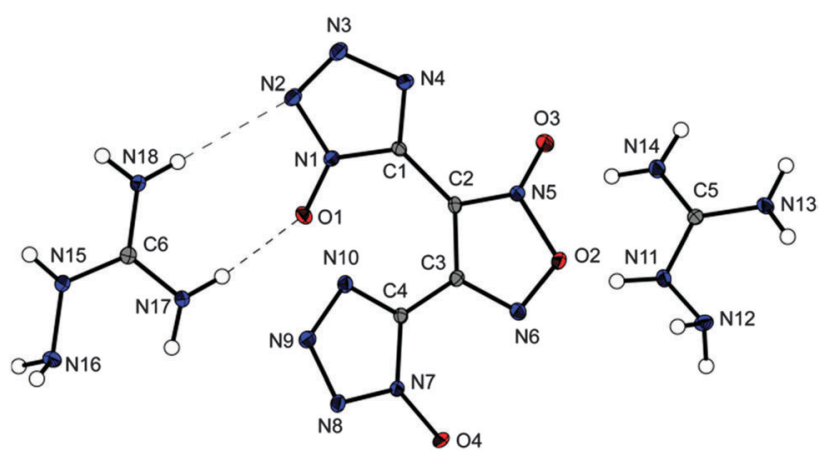

Fig. 9 Molecular moiety of aminoguanidinium salt 23. Thermal ellipsoids are drawn at the $50 \%$ probability level.

In contrast to $\mathbf{2 0}$, the aminoguanidinium salt 23 shows a slightly lower crystal density of $1.692 \mathrm{~g} \mathrm{~cm}^{-3}$. The asymmetric unit of the monoclinic $\left(P 2_{1} / c\right)$ cell is shown in Fig. 9.

\section{NMR spectroscopy}

All ${ }^{1} \mathrm{H}$ NMR and ${ }^{13} \mathrm{C}$ NMR shifts of compounds 1-23 are gathered in Table 1 . The ${ }^{1} \mathrm{H}$ NMR spectra of $\mathbf{9}$ and $\mathbf{1 0}$ exhibit both a broad singlet at around $7 \mathrm{ppm}$ although $\mathbf{1 0}$ has no

Table $1{ }^{1} \mathrm{H}$ NMR and ${ }^{13} \mathrm{C}$ NMR shifts of all compounds

\begin{tabular}{lll}
\hline $\mathrm{C}$ & ${ }^{1} \mathrm{H}$ NMR shift $[\mathrm{ppm}]$ & ${ }^{13} \mathrm{C}$ NMR shift $[\mathrm{ppm}]$ \\
\hline 1 & - & $136.3,106.7$ \\
2 & - & $134.7,106.8,105.0,99.5$ \\
3 & $10.33,6.20$ & $148.7,142.1$ \\
4 & $10.64,10.08,6.98,6.08$ & $151.6,142.5,139.8,109.9$ \\
5 & 13.61 & $148.7,122.9$ \\
6 & $13.78,13.58$ & $150.6,124.8,120.3,110.2$ \\
7 & 12.85 & $147.1,132.6$ \\
8 & $13.00,12.75$ & $149.4,133.7,130.4,107.7$ \\
9 & 9.02 & $142.1,136.6$ \\
10 & 6.67 & $143.4,136.8,134.4,103.4$ \\
11 & - & $145.0,132.8$ \\
12 & - & $147.7,133.2,130.3,106.5$ \\
13 & 10.22 & $144.2,133.9$ \\
14 & 10.27 & $146.4,134.3,131.5,105.6$ \\
15 & 7.18 & $144.8,133.1$ \\
16 & 7.22 & $147.2,133.5,130.7,106.1$ \\
17 & 7.09 & $144.8,133.1$ \\
18 & 7.16 & $147.1,133.7,130.9,106.1$ \\
19 & 6.63 & $158.1,144.2,132.9$ \\
20 & 6.99 & $158.5,146.9,133.8,130.9,105.9$ \\
21 & - & $146.2,133.2,130.4,105.4$ \\
22 & 6.36 & $158.4,145.6,135.1,132.5,105.0$ \\
23 & $8.70,7.26,6.90,4.51$ & $159.4,147.0,133.8,130.9,106.0$
\end{tabular}




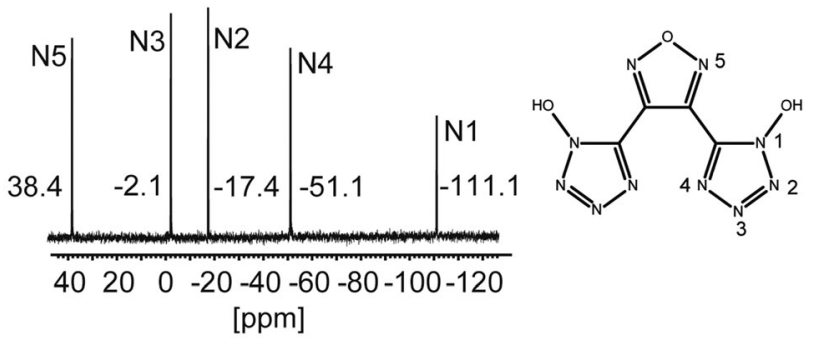

Fig. $10{ }^{15} \mathrm{~N}\left\{{ }^{1} \mathrm{H}\right\}$ NMR spectrum of $\mathbf{9}$.

$C_{2 \mathrm{~V}}$ symmetry anymore. The oximes in compounds 3-8 are observed in low field regions from 10.33 to $13.00 \mathrm{ppm}$. In the case of the oxime and amide protons splitting of the signals of the furoxane compounds can be observed because of the lower symmetry. In the ${ }^{13} \mathrm{C}$ NMR spectrum 9 exhibits two resonances at $142.1 \mathrm{ppm}$ caused by furazane and $136.6 \mathrm{ppm}$ caused by 1-hydroxytetrazole. 10 shows four resonances in the ${ }^{13} \mathrm{C}$ NMR spectra because of the lower symmetry at 136.8 and $134.4 \mathrm{ppm}$ for the tetrazole oxides and at $\mathbf{1 4 3 . 4}$ and $103.4 \mathrm{ppm}$ for the furoxane ring. Upon deprotonation the furazane signal of $\mathbf{9}$ is shifted towards lower fields up to $148.7 \mathrm{ppm}$ and the tetrazole-oxide signal is shifted towards higher fields down to $132.8 \mathrm{ppm}$. The same trend was observed for 10. Deprotonation led to a shift towards lower fields up to 149.4 and $107.7 \mathrm{ppm}$ for furoxane but to a shift towards higher fields down to 133.2 and $130.3 \mathrm{ppm}$ for the tetrazole-oxide resonances. The ${ }^{15} \mathrm{~N}$ NMR spectrum of 9 is depicted in Fig. 10. The chemical shifts are assigned to the particular nitrogen atoms.

The carbon signals of the salts 11-23 are shifted to lower fields in comparison with their acids. No irregularities in the ${ }^{1} \mathrm{H}$ NMR and ${ }^{13} \mathrm{C}$ NMR shifts of the nitrogen-rich cations were observed.

\section{Energetic properties}

Thermal behavior (DSC). The thermal behaviour of the most important salts (with respect to their energetic behavior) of 9 and $\mathbf{1 0}$ is depicted in Fig. 11. The highest thermal stabilities of bis(1-oxidotetrazolyl)furaz(ox)anes are reached by the potassium salts at $277{ }^{\circ} \mathrm{C}(\mathbf{1 1})$ and $265^{\circ} \mathrm{C}(\mathbf{1 2})$, respectively.

Heats of formation, sensitivities and detonation parameters. Gas phase heats of formation $\left(\Delta_{\mathrm{f}} H_{(\mathrm{g}, \mathrm{M}, 298)}^{\circ}\right)$ were calculated theoretically using the atomization eqn (1) and CBS-4M electronic enthalpies. Details of the computations and the conversion of gas phase values into solid state values are given in the ESI.

$$
\Delta_{\mathrm{f}} H_{(\mathrm{g}, \mathrm{M}, 298)}^{\circ}=H_{(\mathrm{M}, 298)}-\Sigma H_{(\text {atoms,298) }}^{\circ}+\Sigma \Delta_{\mathrm{f}} H_{(\text {atoms,298) }}^{\circ}
$$

Sensitivities were measured using a BAM drop hammer, a BAM friction tester ${ }^{12}$ and a OZM electrostatic discharge device $^{13}$ (see also the Experimental part, General methods).

Detonation parameters were calculated using the computer code EXPLO5.05 ${ }^{14}$ using X-ray densities which were converted to room temperature values according to eqn (2). A coefficient of

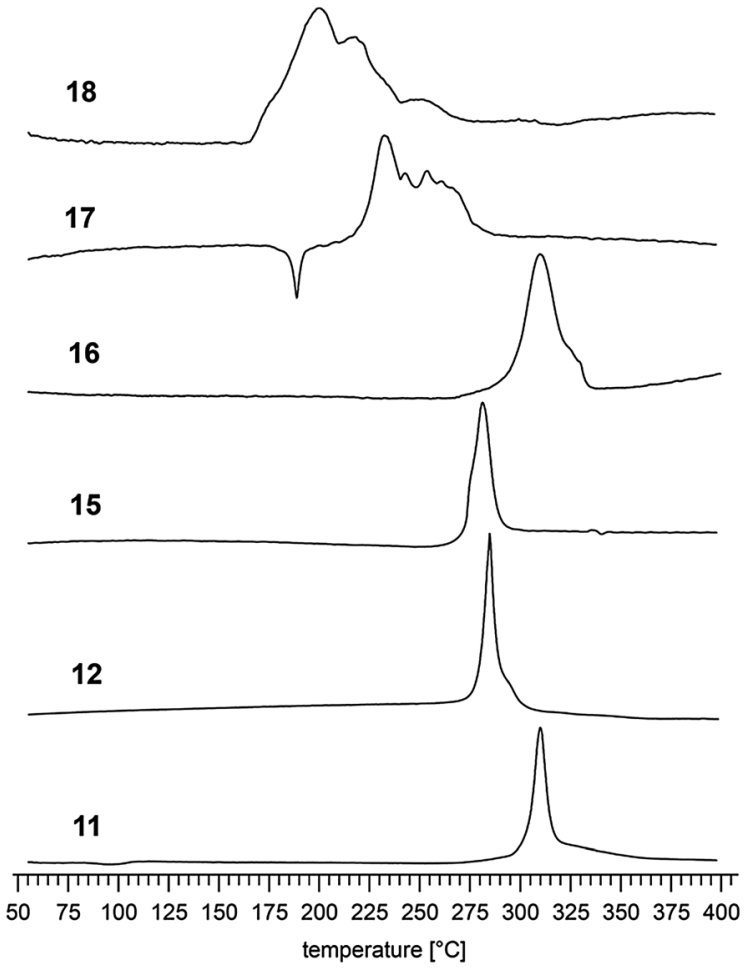

Fig. 11 DSC plots of compounds $11,12,15,16,17$ and 18 at $5^{\circ} \mathrm{C} \mathrm{min}-1$.

volume expansion ${ }^{15} \alpha_{\mathrm{v}}$ of $1.5 \times 10^{-4} \mathrm{~K}^{-1}$ was used. The structures of 15 and 16 were already measured at room temperature. Further explanations are gathered in the ESI.\$

$$
\rho_{298 \mathrm{~K}}=\rho_{T} /\left(1+\alpha_{\mathrm{v}}\left(298-T_{0}\right)\right)
$$

Only the physicochemical properties of compounds $\mathbf{4 , 5}$, 15-16, 20 and 23 are discussed since (i) they consist only of CHNO atoms and (ii) anhydrous crystal structures were obtained. The energetic parameters in comparison with RDX (cyclotrimethylene-trinitramine) are summarized in Table 2. All compounds investigated show improved sensitivities to RDX (IS 7.4 J, FS $120 \mathrm{~N}$ ). Especially 20 is classified as insensitive towards impact and friction. The highest heat of formation was calculated for hydrazinium salt $17\left(\Delta_{\mathrm{f}} H_{(\mathrm{s})}^{\circ}=\right.$ $947.5 \mathrm{~kJ} \mathrm{~mol}^{-1}$ ). For energetic materials it is more convenient to look for mass based enthalpies or energies. Also the highest mass based energy of formation value $\left(\Delta_{\mathrm{f}} U^{\circ} 3245.4 \mathrm{~kJ} \mathrm{~kg}^{-1}\right)$ was calculated for 17 . The most important detonation parameters (heat of detonation, detonation temperature, pressure, velocity of detonation, and volume of detonation gases) were calculated with the EXPLO5.05 code and are summarized in Table 2. Based on these computations, compound $\mathbf{1 7}$ $\left(8843 \mathrm{~m} \mathrm{~s}^{-1}\right.$ ) has higher velocity of detonation than RDX $\left(8763 \mathrm{~m} \mathrm{~s}^{-1}\right)$. However, with respect to the synthetic expenditures and the assessment of all important energetic properties (sensitivities, stabilities and performance) probably none of the compounds will be used as an explosive filler by itself. 
Table 2 Energetic properties of 3, 4, 15-17, 20 and 23

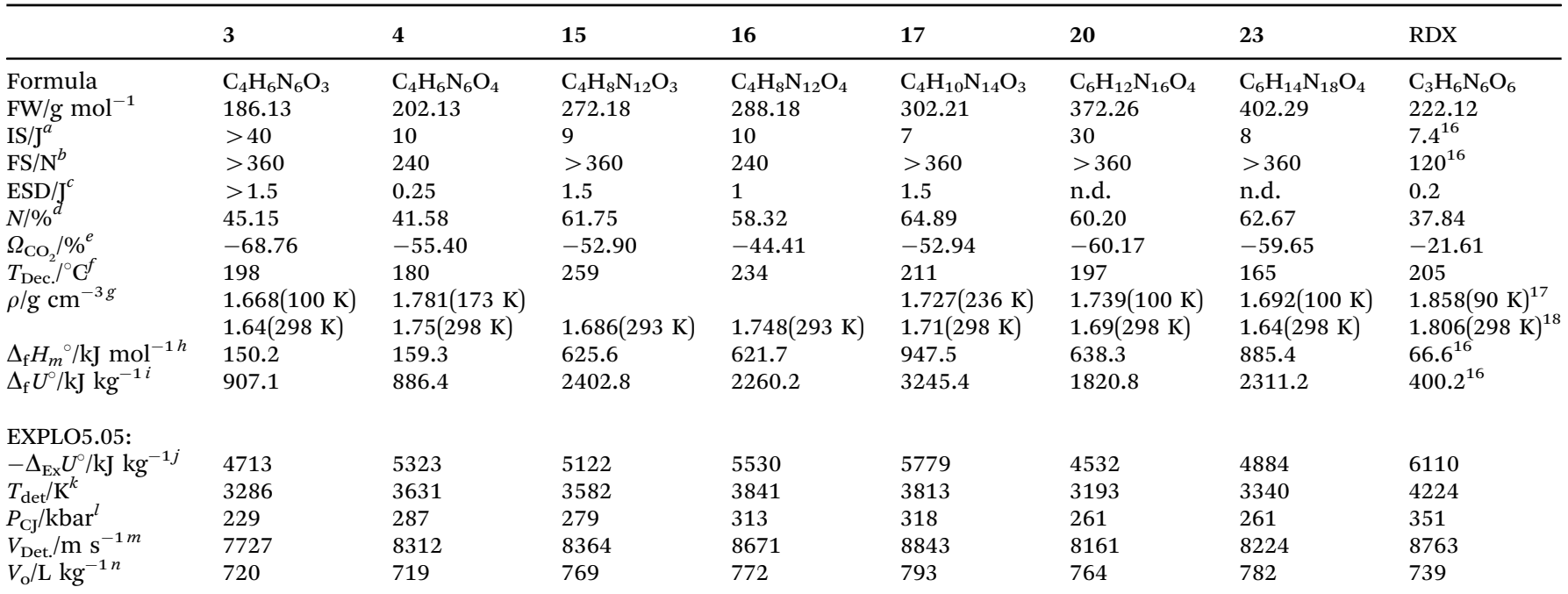

${ }^{a}$ Impact sensitivity (BAM drophammer $(1$ of 6$\left.)\right) .{ }^{b}$ Friction sensitivity (BAM friction tester $(1$ of 6$\left.)\right) .{ }^{c}$ Electrostatic discharge device (OZM research). ${ }^{d}$ Nitrogen content. ${ }^{e}$ Oxygen balance $(\Omega=(x \mathrm{O}-2 y \mathrm{C}-1 / 2 z \mathrm{H}) \mathrm{M} / 1600) .{ }^{f}$ Start of decomposition temperature from DSC $\left(\beta=5{ }^{\circ} \mathrm{C}\right) .{ }^{g}$ From X-ray diffraction, values for $298 \mathrm{~K}$ were calculated with $\rho_{298 \mathrm{~K}}=\rho_{T} /\left(1+\alpha_{\mathrm{v}}(298-T)\right),{ }^{15} \alpha_{\mathrm{v}}=1.5 \times 10^{-4} \mathrm{~K}^{-1} \cdot{ }^{h}$ Calculated enthalpy of formation. ${ }^{i}$ Calculated energy of formation. ${ }^{j}$ Energy of explosion. ${ }^{k}$ Explosion temperature. ${ }^{l}$ Detonation pressure. ${ }^{m}$ Detonation velocity. ${ }^{n}$ Volume of detonation gases (assuming only gaseous products).

\section{Conclusions}

From this combined experimental and theoretical study the following conclusions can be drawn.

- The combination of furazanes or furoxanes with tetrazole1-oxides is a suitable strategy in order to generate new triheterocyclic high-performing energetic materials due to their large positive heats of formation and appropriate densities.

- Generally the investigated furoxanes show mostly higher densities but lower thermal stabilities than the corresponding furazanes. Therefore, furazanes mostly are the better choice as energetic backbone heterocycles.

- The thermal stability of the tetrazole oxide anions attached to a furoxane or furazane ring is sufficient to reach decomposition temperatures above $200{ }^{\circ} \mathrm{C}$.

\section{Experimental part}

For general methods, please see the ESI.

\section{Syntheses}

Bisaminohydroximoylfurazane (3). $10.8 \mathrm{~g}$ (90 mmol) of 1 was dissolved in $45 \mathrm{~mL}$ of ethanol and added within $15 \mathrm{~min}$ to $22.2 \mathrm{~g}$ (336 mmol) of 50\% hydroxylamine solution, which was diluted with $90 \mathrm{~mL}$ of ethanol. The solvent was removed under reduced pressure until crystallization started. Upon filtering $9.3 \mathrm{~g}(50 \mathrm{mmol}, 55 \%)$ of 3 were obtained as a yellowish powder. DSC $\left(5{ }^{\circ} \mathrm{C} \mathrm{min}{ }^{-1}\right): 193$ (mp.), $198{ }^{\circ} \mathrm{C}$ (dec.). Raman (1064 nm, $400 \mathrm{~mW}, 25^{\circ} \mathrm{C}$ ), $\tilde{\nu}$ (rel. int.): 3162 (6), 1651 (71), 1592 (17), 1535 (35), 1513 (100), 1374 (43), 1282 (6), 1126 (6), 1040 (16), 984 (32), 956 (9), 923 (8), 826 (4), 761 (6), 488 (14) $\mathrm{cm}^{-1} \cdot{ }^{1} \mathrm{H}$ NMR (270 MHz, DMSO- $d_{6}, 25{ }^{\circ} \mathrm{C}$ ), $\delta: 10.33,6.20 \mathrm{ppm} .{ }^{13} \mathrm{C}\left\{{ }^{1} \mathrm{H}\right\}$ NMR $\left(270 \mathrm{MHz}\right.$, DMSO- $\left.d_{6}, 25^{\circ} \mathrm{C}\right), \delta: 148.7,142.1 \mathrm{ppm}$.
Bisaminohydroximoylfuroxane (4). $1.4 \mathrm{~g}$ of dicyanofuroxane $(10 \mathrm{mmol}$ ) was dissolved in $30 \mathrm{~mL}$ of ethanol and $1.3 \mathrm{~g}$ of $50 \%$ hydroxylamine solution in $10 \mathrm{~mL}$ of ethanol was added. After stirring for $30 \mathrm{~min}$ the solvent was removed and the residue was suspended in $20 \mathrm{~mL}$ of diethyl ether. The solid was filtered yielding $1.7 \mathrm{~g}(8.4 \mathrm{mmol}, 84 \%)$ of the yellowish product. DSC $\left(5{ }^{\circ} \mathrm{C} \min ^{-1}\right): 180$ (dec.) ${ }^{\circ} \mathrm{C}$. IR (ATR, $25{ }^{\circ} \mathrm{C}$ ), $\tilde{\nu}$ (rel. int.): 3463 (w), 3371 (w), 3309 (w), 1668 (m), 1647 (s), 1579 (s), 1539 (w), 1504 (m), $1418(\mathrm{~m}), 1360(\mathrm{~m}), 1311(\mathrm{~m}), 1229(\mathrm{w}), 1082(\mathrm{w}), 1021(\mathrm{w})$, 951 (s), 929 (s), 858 (w), 810 (m), 744 (vs), $688(\mathrm{~s}) \mathrm{cm}^{-1}$. Raman (1064 nm, $400 \mathrm{~mW}, 25^{\circ} \mathrm{C}$ ), $\tilde{\nu}$ (rel. int.): 3372 (12), 1671 (39), 1651 (34), 1582 (13), 1542 (100), 1507 (12), 1421 (20), 1310 (14), 1232 (14), 1107 (10), 1066 (10), 1021 (10), 956 (9), 933 (11), 860 (6), 756 (10), 639 (6), 480 (24), 370 (5), 330 (11), 299 (5), 263 (6) $\mathrm{cm}^{-1} .{ }^{1} \mathrm{H}$ NMR $\left(270 \mathrm{MHz}\right.$, DMSO- $\left.d_{6}, 25{ }^{\circ} \mathrm{C}\right), \delta: 10.64,10.08$, 6.98, $6.08 \mathrm{ppm} .{ }^{13} \mathrm{C}\left\{{ }^{1} \mathrm{H}\right\}$ NMR $\left(270 \mathrm{MHz}\right.$, DMSO- $\left.d_{6}, 25{ }^{\circ} \mathrm{C}\right), \delta$ : 151.6, 142.5, 139.8, 109.9 ppm. EA $\left(\mathrm{C}_{4} \mathrm{H}_{6} \mathrm{~N}_{6} \mathrm{O}_{4}, 202.13 \mathrm{~g} \mathrm{~mol}^{-1}\right)$ calc. (found): C 23.77 (23.99), H 2.99 (2.86), N 41.58 (41.45)\%. IS: $10 \mathrm{~J}(<100 \mu \mathrm{m})$. FS: $240 \mathrm{~N}$. ESD: $0.25 \mathrm{~J}$.

Bischlorohydroximoylfurazane (5). $6.9 \mathrm{~g}(37 \mathrm{mmol})$ of 3 was dissolved in $200 \mathrm{~mL}$ of semi-conc. hydrochloric acid. A solution of $6.3 \mathrm{~g}$ ( $92 \mathrm{mmol})$ of sodium nitrite in $30 \mathrm{~mL}$ of water was added dropwise within one hour while maintaining the temperature below $0{ }^{\circ} \mathrm{C}$. The solution was stirred for one hour, allowed to come to ambient temperature, diluted with $200 \mathrm{~mL}$ of water and was extracted with $4 \times 35 \mathrm{~mL}$ of diethyl ether. The organic phase was dried over magnesium sulfate and the solvent was removed under reduced pressure to obtain $7.97 \mathrm{~g}$ ( $35 \mathrm{mmol}, 96 \%$ ) of 5 as an oily liquid which partially started to crystallize.

DSC $\left(5{ }^{\circ} \mathrm{C} \min ^{-1}\right): 115{ }^{\circ} \mathrm{C}$ (dec.). IR (ATR, $\left.25{ }^{\circ} \mathrm{C}\right), \tilde{\nu}$ (rel. int.): $3502(\mathrm{~m}), 3388(\mathrm{~m}), 2991(\mathrm{w}), 2877(\mathrm{w}), 1731(\mathrm{w}), 1607$ (m), 1561 (w), 1507 (w), 1499 (w), 1397 (m), 1390 (m), 1376 (m), 1359 (m), 
1343 (m), 1265 (m), 1193 (w), 1094 (vw), 1057 (s), 1032 (s), 999 (s), 962 (s), 900 (s), 887 (vs), 863 (s), 818 (m), 795 (w), 749 (vw), $664(\mathrm{~m}) \mathrm{cm}^{-1}$. Raman (1064 nm, $\left.400 \mathrm{~mW}, 25{ }^{\circ} \mathrm{C}\right), \tilde{\nu}$ (rel. int.): 3397 (6), 2944 (9), 2245 (3), 1626 (9), 1611 (100), 1563 (14), 1509 (89), 1396 (16), 1374 (3), 1361 (2), 1273 (3), 160 (8), 1002 (3), 968 (4), 889 (18), 864 (2), 666 (29), 655 (6), 616 (5), 601 (7), 499 (7), 430 (13), 413 (3), 366 (4), 325 (7), 296 (9), 241 (19), 226 (10), 182 (8), 151 (10), 102 (55), 76 (11), 67 (6) $\mathrm{cm}^{-1} .{ }^{1} \mathrm{H}$ NMR $(270 \mathrm{MHz}$, DMSO- $\left.d_{6}, 25{ }^{\circ} \mathrm{C}\right), \delta: 13.61 \mathrm{ppm} .{ }^{13} \mathrm{C}\left\{{ }^{1} \mathrm{H}\right\}$ NMR (270 MHz, DMSO$\left.d_{6}, 25^{\circ} \mathrm{C}\right), \delta: 148.7,122.9 \mathrm{ppm} . \mathrm{EA}\left(\mathrm{C}_{4} \mathrm{H}_{2} \mathrm{~N}_{4} \mathrm{O}_{3} \mathrm{Cl}_{2}, 224.99 \mathrm{~g} \mathrm{~mol}^{-1}\right)$ calc. (found): C 21.35 (23.19), H 0.90 (1.53), N 24.90 (22.76)\%.

Bischlorohydroximoylfuroxane (6). 4 (34.8 g, $0.2 \mathrm{~mol})$ was dissolved in $500 \mathrm{~mL}$ of $34 \%$ hydrochloric acid (595 g, $6.0 \mathrm{~mol}$ ). The solution was cooled with a salt-ice bath and additionally $500 \mathrm{~g}$ of ice was added to the solution. Sodium nitrite $(31.1 \mathrm{~g}$, $0.5 \mathrm{~mol}$ ) was dissolved in little water and added dropwise over $1 \mathrm{~h}$ while keeping the temperature below $0{ }^{\circ} \mathrm{C}$. Afterwards the solution was allowed to warm to ambient temperature and diluted by addition of $1 \mathrm{~L}$ of ice water. The product was extracted three-times with $200 \mathrm{~mL}$ of diethyl ether and dried over magnesium sulfate. 6 was obtained as a slightly yellow oily liquid which partially started to crystallize to give a total yield of $41.1 \mathrm{~g}$ (170 mmol, 81\%). ${ }^{1} \mathrm{H}$ NMR (270 MHz, DMSO- $\left.d_{6}, 25{ }^{\circ} \mathrm{C}\right), \delta$ : 13.78, 13.58 ppm. ${ }^{13} \mathrm{C}\left\{{ }^{1} \mathrm{H}\right\}$ NMR $\left(270 \mathrm{MHz}\right.$, DMSO- $\left.d_{6}, 25{ }^{\circ} \mathrm{C}\right), \delta$ : 150.6, 124.8, 120.3, 110.2 ppm.

Bisazidohydroximoylfurazane (7). $7.96 \mathrm{~g}$ (35 mmol) of 5 was dissolved in $50 \mathrm{~mL}$ of ethanol and $6.53 \mathrm{~g}(100 \mathrm{mmol})$ of sodium azide in $50 \mathrm{~mL}$ water was added at $0-5{ }^{\circ} \mathrm{C}$. The suspension was stirred for $1 \mathrm{~h}$ on ice, diluted with $100 \mathrm{~mL}$ of water and brought to $\mathrm{pH} 2$ using $2 \mathrm{M}$ hydrochloric acid. The product was extracted with $5 \times 30 \mathrm{~mL}$ of diethyl ether. The organic phase was dried over magnesium sulfate. The product does not need to be isolated for the continuing steps. If the solvent is removed a yellowish oil is obtained in approx. $80 \%$ yield which partially starts to crystallize on standing. IR (ATR, $25{ }^{\circ} \mathrm{C}$ ), $\tilde{\nu}$ (rel. int.): 3258 (m), $3035(\mathrm{w}), 2981(\mathrm{w}), 2855(\mathrm{w}), 2361(\mathrm{vw}), 2325(\mathrm{vw}), 2132(\mathrm{~s})$, $1733(\mathrm{w}), 1614(\mathrm{~m}), 1558(\mathrm{vw}), 1516(\mathrm{w}), 1445(\mathrm{w}), 1389(\mathrm{~m})$, 1340 (s), 1272 (s), 1223 (m), 1108 (vw), 1093 (w), 1026 (s), 976 (vs), $936(\mathrm{~s}), 899(\mathrm{~m}), 855$ (s), $819(\mathrm{w}), 781(\mathrm{vw}), 753(\mathrm{w}), 668(\mathrm{vw}) \mathrm{cm}^{-1}$. ${ }^{1} \mathrm{H}$ NMR $\left(270 \mathrm{MHz}\right.$, DMSO- $\left.d_{6}, 25{ }^{\circ} \mathrm{C}\right), \delta: 12.85 \mathrm{ppm} .{ }^{13} \mathrm{C}\left\{{ }^{1} \mathrm{H}\right\} \mathrm{NMR}$ $\left(270 \mathrm{MHz}, \mathrm{DMSO}-d_{6}, 25{ }^{\circ} \mathrm{C}\right), \delta: 147.1,132.6 \mathrm{ppm}$.

Bisazidohydroximoylfuroxane (8). 6 (3.9 g, $16 \mathrm{mmol})$ was dissolved in $20 \mathrm{~mL}$ of ethanol and cooled with an ice bath while an aqueous solution of sodium azide (2.6 g, $40 \mathrm{mmol}$ ) was added in small portions. After the addition of sodium azide, the mixture was stirred for $1 \mathrm{~h}$. The yellowish solution was diluted with $70 \mathrm{~mL}$ of ice water, adjusted to $\mathrm{pH} 1$ by addition of concentrated hydrochloric acid and extracted with $3 \times 30 \mathrm{~mL}$ and $1 \times 10 \mathrm{~mL}$ of diethyl ether. The organic phase was dried over magnesium sulfate and the solvent was removed under reduced pressure. 8 was obtained as a yellowish oil in approx. $80 \%$ yield. ${ }^{1} \mathrm{H}$ NMR (270 MHz, DMSO- $\left.d_{6}, 25{ }^{\circ} \mathrm{C}\right), \delta: 13.00$, 12.75 ppm. ${ }^{13} \mathrm{C}\left\{{ }^{1} \mathrm{H}\right\}$ NMR (270 MHz, DMSO- $\left.d_{6}, 25{ }^{\circ} \mathrm{C}\right), \delta$ : 149.4, 133.7, 130.4, 107.7 ppm.

Bis(1-hydroxytetrazolyl)furazane (9). The ethereal solution of 7 was saturated with gaseous $\mathrm{HCl}$ below $5{ }^{\circ} \mathrm{C}$, the reaction flask was sealed and was then allowed to come to ambient temperature and stirred overnight. The solvent was removed under reduced pressure and bis(1-hydroxytetrazolyl)furazane was obtained as a yellowish oily liquid. DSC $\left(5{ }^{\circ} \mathrm{C} \min ^{-1}\right): 91{ }^{\circ} \mathrm{C}$ (dec.). IR (ATR, $25^{\circ} \mathrm{C}$ ), $\tilde{\nu}$ (rel. int.): 3404 (w), 2255 (w), 2128 (w), 1713 (w), 1660 (m), 1463 (m), 1344 (m), 1246 (m), 1197 (m), 1103 (m), 1053 (s), 1022 (s), 1005 (s), 982 (s), 922 (s), 895 (s), 819 (vs), 758 (s), 729 (s), $709(\mathrm{~m}), 686(\mathrm{~m}), 673(\mathrm{~m}) \mathrm{cm}^{-1}$. Raman (1064 nm, $400 \mathrm{~mW}, 25{ }^{\circ} \mathrm{C}$ ), $\tilde{\nu}$ (rel. int.): 2982 (8), 2940 (70), 2878 (14), 1618 (100), 1453 (10), 1387 (7), 1261 (30), 1205 (6), 1111 (5), 1011 (8), 907 (10), 764 (5), 736 (15), 711 (5), 455 (10), 92 (38) $\mathrm{cm}^{-1} .{ }^{1} \mathrm{H}$ NMR (270 MHz, DMSO- $\left.d_{6}, 25{ }^{\circ} \mathrm{C}\right), \delta: 9.02 \mathrm{ppm}$. ${ }^{13} \mathrm{C}\left\{{ }^{1} \mathrm{H}\right\}$ NMR $\left(270 \mathrm{MHz}, \mathrm{DMSO}-d_{6}, 25{ }^{\circ} \mathrm{C}\right), \delta: 142.1,136.6 \mathrm{ppm}$. ${ }^{15} \mathrm{~N}\left\{{ }^{1} \mathrm{H}\right\}$ NMR (400 MHz, DMSO- $\left.d_{6}, 25{ }^{\circ} \mathrm{C}\right), \delta: 38.39,-2.1,-17.4$, $-51.1,-111.1 \mathrm{ppm}$.

Bis(1-hydroxytetrazolyl)furoxane (10). The oily compound 8 (3.3 g, $13 \mathrm{mmol}$ ) was dissolved in $100 \mathrm{~mL}$ of diethyl ether. Gaseous $\mathrm{HCl}$ was passed through the reaction mixture until saturation was reached at $0-5{ }^{\circ} \mathrm{C}$ and the reaction flask was sealed. After stirring overnight at room temperature the solvent was removed and bis(1-hydroxytetrazolyl)furoxane remained as a yellowish resinous substance. IR (ATR, $25{ }^{\circ} \mathrm{C}$ ), $\tilde{\nu}$ (rel. int.): 3423 (w), 2460 (w), 1607 (vs), 1461 (w), 1402 (w), 1369 (m), 1301 (m), 1259 (m), $1223(\mathrm{~m}), 1194(\mathrm{w}), 1135(\mathrm{w}), 1091(\mathrm{w})$, 1000 (m), 965 (s), 816 (s), 762 (w), 744 (w), 728 (w), 696 (w) cm cm $^{-1}$ Raman (1064 nm, $400 \mathrm{~mW}, 25{ }^{\circ} \mathrm{C}$ ), $\tilde{\nu}$ (rel. int.): 2997 (2), 2990 (2), 2982 (7), 2943 (44), 1612 (100), 1463 (12), 1309 (14), 1265 (35), 1227 (31), 1201 (6), 1138 (6), 1003 (12), 820 (8), 765 (9), 747 (13), 733 (14), 700 (7), 526 (7), 453 (10), 414 (6), 388 (6), 358 (8) $\mathrm{cm}^{-1} .{ }^{1} \mathrm{H}$ NMR (270 MHz, DMSO- $\left.d_{6}, 25{ }^{\circ} \mathrm{C}\right), \delta: 6.67 \mathrm{ppm}$. ${ }^{13} \mathrm{C}\left\{{ }^{1} \mathrm{H}\right\}$ NMR $\left(270 \mathrm{MHz}\right.$, DMSO- $\left.d_{6}, 25{ }^{\circ} \mathrm{C}\right), \delta: 143.4,136.8,134.4$, 103.4 ppm.

Dipotassium bis(1-oxidotetrazolyl)furazane (11). An aqueous solution of 9 was brought to $\mathrm{pH} 8$ with $2 \mathrm{M}$ potassium hydroxide solution. The solution was left for crystallization and the dihydrate of $\mathbf{1 1}$ was obtained as a crystalline solid. The anhydrous compound was obtained by pouring a hot concentrated aqueous solution of $\mathbf{1 1}$ into the five-fold volume of ethanol and filtering. DSC $\left(5{ }^{\circ} \mathrm{C} \min ^{-1}\right): 87{ }^{\circ} \mathrm{C}$ (dehy), $277{ }^{\circ} \mathrm{C}$ (dec.). IR (ATR, $25^{\circ} \mathrm{C}$ ), $\tilde{\nu}$ (rel. int.): 3552 (w), 3357 (m), 3242 (w), 1665 (w), 1635 (m), 1592 (m), 1574 (w), 1542 (w), 1471 (s), 1437 (m), 1407 (s), 1372 (m), 1362 (m), 1286 (s), 1239 (s), 1173 (w), 1118 (m), 1084 (w), 1033 (m), 1015 (w), 1000 (s), 983 (vs), 912 (s), $896(\mathrm{~m}), 834(\mathrm{w}), 803(\mathrm{w}), 771(\mathrm{~m}), 751(\mathrm{w}), 727(\mathrm{w}), 692(\mathrm{w}), 664$ (w) $\mathrm{cm}^{-1}$. Raman (1064 nm, $\left.400 \mathrm{~mW}, 25{ }^{\circ} \mathrm{C}\right), \tilde{\nu}$ (rel. int.): 1594 (26), 1575 (100), 1473 (6), 1374 (13), 1240 (11), 1176 (12), 1145 (8), 1121 (4), 1085 (3), 1017 (5), 1004 (3), 774 (5), 457 (5), 98 (13), $79(5) \mathrm{cm}^{-1} \cdot{ }^{13} \mathrm{C}\left\{{ }^{1} \mathrm{H}\right\}$ NMR (270 MHz, DMSO- $\left.d_{6}, 25{ }^{\circ} \mathrm{C}\right), \delta: 145.0$, 132.8. $\mathrm{EA}\left(\mathrm{K}_{2} \mathrm{C}_{4} \mathrm{H}_{4} \mathrm{~N}_{10} \mathrm{O}_{5}, 386.37 \mathrm{~g} \mathrm{~mol}^{-1}\right)$ calc. (found): $\mathrm{C} 12.43$ (13.60), H 1.04 (1.22), N 36.25 (36.72)\%. $\mathrm{MS}\left(\mathrm{FAB}^{+}\right) \mathrm{m} / z: 39.0$ $\left[\mathrm{K}^{+}\right],\left(\mathrm{FAB}^{-}\right) m / z: 237.2\left[\mathrm{C}_{4} \mathrm{HN}_{10} \mathrm{O}_{3}{ }^{-}\right]$. IS: $35 \mathrm{~J}(<100 \mu \mathrm{m})$, FS: $>360$ N. ESD: $1.5 \mathrm{~J}$.

Dipotassium bis(1-oxidotetrazolyl)furoxane (12). The total amount of 10 was suspended in $50 \mathrm{~mL}$ of ethanol and an aqueous solution of potassium hydroxide was added until pH 7 was reached. The potassium salt started to precipitate. After 
addition of $20 \mathrm{~mL}$ of diethyl ether more precipitate could be obtained. Filtration of the mixture and air drying led to $4.9 \mathrm{~g}$ (15 mmol, 94\% based on step 6) of a white powder. DSC $\left(5{ }^{\circ} \mathrm{C} \min ^{-1}\right): 265{ }^{\circ} \mathrm{C}$ (dec.). IR (ATR, $25{ }^{\circ} \mathrm{C}$ ), $\tilde{\nu}$ (rel. int.): 3376 (w), 3142 (w), 3087 (w), 2841 (w), 2799 (w), 2652 (w), 2449 (w), 2357 (w), $2343(\mathrm{w}), 2167(\mathrm{w}), 2000(\mathrm{w}), 1799(\mathrm{w}), 1703(\mathrm{w}), 1670$ (w), 1648 (w), 1609 (s), 1575 (s), 1546 (s), 1464 (m), 1450 (s), 1427 (s), 1421 (s), 1396 (s), 1370 (s), $1297(\mathrm{~m}), 1231$ (vs), 1195 (w), 1167 (m), 1156 (w), $1144(\mathrm{w}), 1115(\mathrm{w}), 1095(\mathrm{~m}), 1035$ (w), 1017 (m), 988 (s), 964 (s), $879(\mathrm{w}), 836(\mathrm{~s}), 792(\mathrm{w}), 767(\mathrm{~s}), 754(\mathrm{~m}), 731$ (m), $711(\mathrm{~m}), 705$ (w), 693 (m), $682(\mathrm{~m}), 654$ (w) cm ${ }^{-1}$. Raman (1064 nm, $400 \mathrm{~mW}, 25{ }^{\circ} \mathrm{C}$ ), $\tilde{\nu}$ (rel. int.): 1616 (22), 1576 (100), 1549 (35), 1449 (11), 1403 (11), 1372 (3), 1299 (5), 1235 (24), 1195 (29), 1170 (19), 1158 (6), 1147 (6), 1098 (6), 1021 (6), 992 (18), 838 (8), 769 (16), 734 (3), 713 (3), 696 (7), 685 (3), 595 (4), 558 (5), 511 (13), 456 (13), 442 (5), 411 (5), 368 (6), 341 (3), 297 (2), 260 (4), 240 (4), 166 (34), 137 (46), 122 (24), 101 (36), 77 (27) $\mathrm{cm}^{-1}$. ${ }^{13} \mathrm{C}\left\{{ }^{1} \mathrm{H}\right\}$ NMR $\left(270 \mathrm{MHz}\right.$, DMSO- $\left.d_{6}, 25{ }^{\circ} \mathrm{C}\right), \delta: 147.7,133.2,130.3$, 106.5. $\mathrm{MS}\left(\mathrm{FAB}^{+}\right): 39.0\left[\mathrm{~K}^{+}\right],\left(\mathrm{FAB}^{-}\right): 253.1\left[\mathrm{C}_{4} \mathrm{HN}_{10} \mathrm{O}_{4}{ }^{-}\right]$. $\mathrm{EA}\left(\mathrm{K}_{2} \mathrm{C}_{4} \mathrm{~N}_{10} \mathrm{O}_{4}, 330.30 \mathrm{~g} \mathrm{~mol}^{-1}\right)$ calc. (found): $\mathrm{C} 14.55$ (14.64), H 0.00 (0.00), N 42.41 (41.38)\%. Found: C 14.64, H 0.00, N 41.38\%. IS: $10 \mathrm{~J}(<100 \mu \mathrm{m})$. Friction tester: $48 \mathrm{~N}(<100 \mu \mathrm{m})$.

Dihydroxylammonium bis(1-oxidotetrazolyl)furazane (13). $3.2 \mathrm{~g}$ (10 mmol) of 11 was dissolved in $20 \mathrm{~mL}$ of $2 \mathrm{M}$ hydrochloric acid. The solution was extracted with $5 \times 30 \mathrm{~mL}$ of diethyl ether and the solvent was removed under reduced pressure. The residue was dissolved in $20 \mathrm{~mL}$ of ethanol. 2.2 eq. of $50 \%$ hydroxylamine solution was added under vigorous stirring. The solution was stirred for additional $30 \mathrm{~min}$, the solvent was then removed under reduced pressure and the precipitate was filtered off. $2.9 \mathrm{~g}$ (9.6 mmol, 95\%) of 13 was obtained as a white crystalline powder. DSC $\left(5{ }^{\circ} \mathrm{C} \mathrm{min}^{-1}\right)$ : $170{ }^{\circ} \mathrm{C}$ (dec.). IR (ATR, $25{ }^{\circ} \mathrm{C}$ ), $\tilde{\nu}$ (rel. int.): 3210 (w), 3043 (w), 2885 (w), 2663 (m), 1992 (w), 1623 (w), 1602 (w), 1497 (m), 1473 (s), 1434 (m), 1429 (m), 1404 (s), 1376 (w), 1361 (s), 1285 (s), 1245 (s), 1230 (s), 1197 (m), 1180 (m), 1126 (w), 1035 (w), 1009 (m), 1000 (s), 986 (vs), $894(\mathrm{~m}), 878(\mathrm{w}), 773(\mathrm{~m}), 748(\mathrm{w}), 694(\mathrm{w})$ $\mathrm{cm}^{-1}$. Raman (1064 nm, $\left.400 \mathrm{~mW}, 25^{\circ} \mathrm{C}\right), \tilde{\nu}$ (rel. int.): 1606 (15), 1588 (100), 1477 (5), 1439 (2), 1376 (14), 1289 (2), 1249 (13), 1236 (4), 1183 (16), 1147 (8), 1128 (4), 1089 (5), 1012 (16), 903 (7), 776 (4), 750 (6), 686 (2), 556 (4), 462 (10), 46 (2), 349 (2), 309 (2), 98 (14) $\mathrm{cm}^{-1} \cdot{ }^{1} \mathrm{H}$ NMR $\left(270 \mathrm{MHz}, \mathrm{DMSO}-d_{6}, 25{ }^{\circ} \mathrm{C}\right), \delta: 10.22 \mathrm{ppm}$. ${ }^{13} \mathrm{C}\left\{{ }^{1} \mathrm{H}\right\}$ NMR $\left(270 \mathrm{MHz}, \mathrm{DMSO}-d_{6}, 25{ }^{\circ} \mathrm{C}\right), \delta: 144.2,133.9 \mathrm{ppm}$. $\mathrm{EA}\left(\mathrm{C}_{4} \mathrm{H}_{8} \mathrm{~N}_{12} \mathrm{O}_{5}, 304.18 \mathrm{~g} \mathrm{~mol}^{-1}\right)$ calc. (found): $\mathrm{C} 15.79(16.39), \mathrm{H}$ 2.65 (2.67), N 55.26 (54.23)\%. IS: 7 J $(<100 \mu \mathrm{m})$. FS: $216 \mathrm{~N}$ $(<100 \mu \mathrm{m})$. ESD $(<100 \mu \mathrm{m}): 1 \mathrm{~J}$.

Dihydroxylammonium bis(1-oxidotetrazolyl)furoxane monohydrate (14). $1.7 \mathrm{~g}$ of $12(5 \mathrm{mmol})$ was dissolved in $20 \mathrm{~mL}$ of $2 \mathrm{M}$ hydrochloric acid and extracted with $4 \times 20 \mathrm{~mL}$ of diethyl ether. The ether was removed under reduced pressure and the residue was dissolved in a few milliliters of water. Hydroxylamine ( $661 \mathrm{mg}$ of $50 \%$ solution in $\mathrm{H}_{2} \mathrm{O}, 0.61 \mathrm{~mL}, 10 \mathrm{mmol}$ ) was added while stirring. The solution was left for crystallisation. Compound 14 crystallized to give $1.7 \mathrm{~g}$ (4.9 mmol, 98\%) yield. DSC $\left(5{ }^{\circ} \mathrm{C} \min ^{-1}\right): 135{ }^{\circ} \mathrm{C}$ (dec.). IR (ATR, $25{ }^{\circ} \mathrm{C}$ ), $\tilde{\nu}$ (rel. int.): 2976 (m), 2709 (m), 1696 (w), 1625 (s), 1591 (s), 1559 (s), 1461 (s),
1426 (m), 1399 (m), 1376 (m), 1300 (m), 1232 (vs), 1187 (m), 1020 (m), 996 (s), 964 (s), 822 (m), 757 (m), $704(\mathrm{w}) \mathrm{cm}^{-1}$. Raman (1064 nm, $400 \mathrm{~mW}, 25{ }^{\circ} \mathrm{C}$ ), $\tilde{\nu}$ (rel. int.): 2986 (13), 1630 (27), 1590 (100), 1567 (29), 1495 (6), 1463 (8), 1398 (14), 1300 (8), 1235 (15), 1212 (44), 1186 (6), 1137 (10), 1102 (5), 1018 (14), 1001 (33), 833 (4), 756 (8), 707 (3), 684 (3), 506 (4), 460 (7). ${ }^{1} \mathrm{H}$ NMR (270 MHz, DMSO- $d_{6}, 25{ }^{\circ} \mathrm{C}$ ), $\delta: 10.27$ ppm. ${ }^{13} \mathrm{C}\left\{{ }^{1} \mathrm{H}\right\}$ NMR $\left(270 \mathrm{MHz}, \mathrm{DMSO}-d_{6}, 25{ }^{\circ} \mathrm{C}\right), \delta: 146.4,134.3,131.5,105.6 \mathrm{ppm}$. $\mathrm{EA}\left(\mathrm{C}_{4} \mathrm{H}_{10} \mathrm{~N}_{12} \mathrm{O}_{7}, 338.20 \mathrm{~g} \mathrm{~mol}^{-1}\right)$ calc. (found): $\mathrm{C} 14.21$ (14.30), H 2.98 (2.90), N 49.70 (48.43)\%. IS: $10 \mathrm{~J}(100-500 \mu \mathrm{m})$. FS: 240 $\mathrm{N}(100-500 \mu \mathrm{m})$.

Diammonium bis(1-oxidotetrazolyl)furazane (15). $3.1 \mathrm{~g}$ (10 mmol) of 11 was dissolved in $20 \mathrm{~mL}$ of $2 \mathrm{M}$ hydrochloric acid. The solution was extracted with $5 \times 30 \mathrm{~mL}$ of diethyl ether and the solvent was removed under reduced pressure. The residue was dissolved in $20 \mathrm{~mL}$ of water. 2.2 eq. of ammonium hydroxide was added under vigorous stirring. The solvent was then removed under reduced pressure. The crude product was recrystallized from methanol, $2.66 \mathrm{~g}$ (8.8 mmol, 87\%) of 11 was obtained as colorless crystals. DSC $\left(5{ }^{\circ} \mathrm{C} \min ^{-1}\right): 259{ }^{\circ} \mathrm{C}$ (dec.). IR (ATR, $25{ }^{\circ} \mathrm{C}$ ), $\tilde{\nu}$ (rel. int.): 3134 (w), 3000 (w), 2881 (w), 2796 (w), $1665(\mathrm{w}), 1604(\mathrm{w}), 1594(\mathrm{w}), 1469(\mathrm{~m}), 1440$ (s), 1405 (s), 1366 (s), 1283 (s), 1229 (vs), 1181 (w), 1133 (w), 1122 (m), 1031 (m), $1014(\mathrm{w}), 1003(\mathrm{~m}), 983$ (s), 905 (s), $889(\mathrm{~m}), 765(\mathrm{w}), 748(\mathrm{~s})$, 731 (w), $716(\mathrm{w}), 696(\mathrm{w}) \mathrm{cm}^{-1}$. Raman (1064 nm, $400 \mathrm{~mW}$, $\left.25{ }^{\circ} \mathrm{C}\right), \tilde{\nu}$ (rel. int.): 1606 (31), 1594 (100), 1482 (4), 1373 (11), 1235 (20), 1182 (16), 1136 (12), 1123 (4), 1015 (6), 1005 (3), 906 (7), 767 (4), 750 (7), 612 (3), 461 (10), 305 (2), 163 (5), 129 (6), 102 (42). ${ }^{1} \mathrm{H}$ NMR (270 MHz, DMSO- $\left.d_{6}, 25{ }^{\circ} \mathrm{C}\right), \delta: 7.18 \mathrm{ppm} .{ }^{13} \mathrm{C}\left\{{ }^{1} \mathrm{H}\right\}$ NMR (270 MHz, DMSO- $\left.d_{6}, 25{ }^{\circ} \mathrm{C}\right), \delta: 144.8,133.1 \mathrm{ppm}$. EA $\left(\mathrm{C}_{4} \mathrm{H}_{8} \mathrm{~N}_{12} \mathrm{O}_{3}, 272.19 \mathrm{~g} \mathrm{~mol}^{-1}\right)$ calc. (found): $\mathrm{C} 17.65$ (17.93), H 2.96 (2.95), N 61.75 (61.00)\%. IS: $9 \mathrm{~J}(<100 \mu \mathrm{m})$. FS: $>360$ $\mathrm{N}(<100 \mu \mathrm{m})$. ESD $(<100 \mu \mathrm{m}): 1.5 \mathrm{~J}$.

Diammonium bis(1-oxidotetrazolyl)furoxane (16). $1.7 \mathrm{~g}$ of 12 (5 mmol) was dissolved in $20 \mathrm{~mL}$ of $2 \mathrm{M}$ hydrochloric acid and extracted with $4 \times 20 \mathrm{~mL}$ of diethyl ether. The solvent was removed under reduced pressure and the residue was dissolved in a few milliliters of water. The solution was adjusted to $\mathrm{pH} 7$ by addition of $2 \mathrm{M} \mathrm{NH}$. The solvent was removed under reduced pressure and $\mathbf{1 6}$ precipitated as a colorless solid to give $1.2 \mathrm{~g}$ ( $4.2 \mathrm{mmol}, 84 \%)$ yield. Crystals of 16 were obtained from water. DSC $\left(5{ }^{\circ} \mathrm{C} \mathrm{min}{ }^{-1}\right)$ : $230{ }^{\circ} \mathrm{C}$ (dec.). IR (ATR, $\left.25{ }^{\circ} \mathrm{C}\right), \tilde{\nu}$ (rel. int.): 3166 (w), 3010 (w), 2892 (w), 2801 (w), 1622 (s), 1583 (m), 1555 (m), 1462 (s), 1426 (s), 1399 (s), 1374 (m), 1297 (m), 1228 (vs), 1181 (w), 1020 (w), 996 (m), 964 (s), 832 (s), 760 (m),

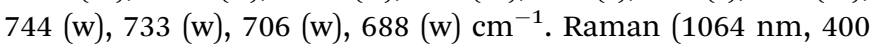
$\mathrm{mW}, 25{ }^{\circ} \mathrm{C}$ ), $\tilde{\nu}$ (rel. int.): 3031 (3), 1622 (29), 1585 (100), 1556 (20), 1398 (10), 1297 (4), 1229 (14), 1207 (28), 1182 (4), 1134 (9), 1102 (4), 1025 (4), 999 (8), 832 (3), 761 (4), 711 (2), 687 (2), 553 (2), 500 (4). ${ }^{1} \mathrm{H}$ NMR (270 MHz, DMSO- $\left.d_{6}, 25{ }^{\circ} \mathrm{C}\right), \delta: 7.22 \mathrm{ppm}$. ${ }^{13} \mathrm{C}\left\{{ }^{1} \mathrm{H}\right\}$ NMR $\left(270 \mathrm{MHz}, \mathrm{DMSO}-d_{6}, 25{ }^{\circ} \mathrm{C}\right), \delta: 147.2,133.5,130.7$, 106.1 ppm. EA $\left(\mathrm{C}_{4} \mathrm{H}_{8} \mathrm{~N}_{12} \mathrm{O}_{4}, 288.18 \mathrm{~g} \mathrm{~mol}^{-1}\right)$ calc. (found): C 16.67 (16.88), H 2.80 (2.82), N 58.32 (56.18)\%. IS: $10 \mathrm{~J}$ $(<100 \mu \mathrm{m})$. FS: $240 \mathrm{~N}(<100 \mu \mathrm{m})$. ESD $(<100 \mu \mathrm{m})$ : $1 \mathrm{~J}$.

Dihydrazinium bis(1-oxidotetrazolyl)furazane (17). $3.2 \mathrm{~g}$ (10 mmol) of 11 was dissolved in $20 \mathrm{~mL}$ of $2 \mathrm{M}$ hydrochloric acid. 
The solution was extracted with $5 \times 30 \mathrm{~mL}$ of diethyl ether and the solvent was removed under reduced pressure. The residue was dissolved in $20 \mathrm{~mL}$ of ethanol and 2.2 eq. of hydrazine hydrate was added under vigorous stirring. The solution was stirred for additional $30 \mathrm{~min}$, the solvent was then concentrated under reduced pressure and the precipitate was filtered off. The crude product was recrystallized from methanol, $2.9 \mathrm{~g}$ (9.4 mmol, 94\%) of 17 was obtained as yellowish crystals. DSC $\left(5{ }^{\circ} \mathrm{C} \min ^{-1}\right): 175{ }^{\circ} \mathrm{C}(\mathrm{mp}$.), $211{ }^{\circ} \mathrm{C}$ (dec.). IR (ATR, $25{ }^{\circ} \mathrm{C}$ ), $\tilde{\nu}$ (rel. int.): 3323 (w), 3187 (w), 2839 (m), 2710 (m), 2640 (m), 1604 (m), 1537 (m), 1471 (m), 1422 (w), 1402 (s), 1374 (w), 1361 (m), 1285 (s), 1232 (m), 1222 (s), 1173 (w), 1141 (m), 1115 (s), 1093 (s), 1078 (s), 1009 (w), 999 (m), 982 (s), 962 (vs), 897 (s), $874(\mathrm{~m}), 768(\mathrm{w}), 758(\mathrm{~m}), 747(\mathrm{~m}), 731(\mathrm{w}), 716(\mathrm{w}), 697$ (w), $689(\mathrm{w}) \mathrm{cm}^{-1}$. Raman (1064 nm, $\left.400 \mathrm{~mW}, 25{ }^{\circ} \mathrm{C}\right), \tilde{\nu}$ (rel. int.): 3326 (3), 3188 (4), 1609 (57), 1587 (100), 1473 (8), 1376 (15), 1235 (16), 1174 (18), 1150 (9), 1137 (5), 1087 (7), 1004 (7), 963 (10), 901 (9), 772 (7), 749 (5), 620 (3), 464 (14), 171 (4), 141 (5), 104 (9), 92 (16). ${ }^{1} \mathrm{H}$ NMR (270 MHz, DMSO- $\left.d_{6}, 25{ }^{\circ} \mathrm{C}\right), \delta: 7.09 \mathrm{ppm} .{ }^{13} \mathrm{C}\left\{{ }^{1} \mathrm{H}\right\}$ NMR $\left(270 \mathrm{MHz}\right.$, DMSO- $\left.d_{6}, 25^{\circ} \mathrm{C}\right), \delta: 144.8,133.1 \mathrm{ppm}$. EA $\left(\mathrm{C}_{4} \mathrm{H}_{10} \mathrm{~N}_{14} \mathrm{O}_{3}\right.$, $302.21 \mathrm{~g} \mathrm{~mol}^{-1}$ ) calc. (found): C 15.90 (16.36), H 3.34 (3.27), N 64.89 (64.45)\%. IS: $7 \mathrm{~J}(<100 \mu \mathrm{m})$. FS: $>360 \mathrm{~N}(<100 \mu \mathrm{m})$. ESD $(<100 \mu \mathrm{m}): 1.5 \mathrm{~J}$.

Dihydrazinium bis(1-oxidotetrazolyl)furoxane (18). $1.7 \mathrm{~g}$ of $12(5.6 \mathrm{mmol})$ was dissolved in $20 \mathrm{~mL}$ of $2 \mathrm{M}$ hydrochloric acid and extracted four-times with $20 \mathrm{~mL}$ of diethyl ether. The solvent was removed under reduced pressure and the residue was dissolved in a few milliliters of water. Hydrazinium hydroxide $(0.5 \mathrm{~g}, 0.5 \mathrm{~mL}, 10 \mathrm{mmol})$ was added to the colorless solution, the solvent was removed under reduced pressure and 18 precipitated as a colorless solid to give $1.5 \mathrm{~g}(4.8 \mathrm{mmol}$, $96 \%$ ) yield. DSC $\left(5{ }^{\circ} \mathrm{C} \min ^{-1}\right): 160{ }^{\circ} \mathrm{C}$ (dec.). IR (ATR, $\left.25{ }^{\circ} \mathrm{C}\right), \tilde{\nu}$ (rel. int.): 3563 (w), 3461 (w), 3344 (m), 3331 (m), 3285 (m), 2833 (m), 2725 (m), 2606 (m), 2105 (m), 1613 (s), 1580 (s), 1551 (s), 1512 (s), 1455 (s), 1426 (s), 1413 (s), 1391 (s), 1371 (s), 1345 (m), 1292 (m), 1230 (s), 1108 (m), 1088 (s), 1018 (m), 984 (s), 956 (s), 942 (vs), 820 (s), 773 (m), 760 (s), 746 (m), 732 (m), 704 (m), 688 (m), $679(\mathrm{~m}) \mathrm{cm}^{-1}$. Raman $\left(1064 \mathrm{~nm}, 400 \mathrm{~mW}, 25{ }^{\circ} \mathrm{C}\right), \tilde{\nu}$ (rel. int.): 1613 (19), 1583 (100), 1554 (12), 1457 (4), 1396 (9), 1295 (3), 1237 (11), 1209 (30), 1181 (7), 1152 (7), 1137 (7), 1096 (7), 1018 (4), 989 (11), 946 (4), 764 (10), 734 (3), 707 (3), 692 (3), 556 (4), 500 (7), 456 (11), 439 (5), 366 (3), 324 (6), 295 (2), 159 (14), 110 (46), $88(45) \mathrm{cm}^{-1} .{ }^{1} \mathrm{H}$ NMR (270 MHz, DMSO- $\left.d_{6}, 25{ }^{\circ} \mathrm{C}\right), \delta: 7.16$ ppm. ${ }^{13} \mathrm{C}\left\{{ }^{1} \mathrm{H}\right\}$ NMR $\left(270 \mathrm{MHz}, \mathrm{DMSO}-d_{6}, 25{ }^{\circ} \mathrm{C}\right), \delta: 147.1,133.7$, 130.9, 106.1 ppm. $\mathrm{MS}\left(\mathrm{FAB}^{+}\right): 33.0\left[\mathrm{~N}_{2} \mathrm{H}_{5}{ }^{+}\right],\left(\mathrm{FAB}^{-}\right): 253.1$ $\left[\mathrm{C}_{4} \mathrm{HN}_{10} \mathrm{O}_{4}{ }^{-}\right]$. EA $\left(\mathrm{C}_{4} \mathrm{H}_{10} \mathrm{~N}_{14} \mathrm{O}_{4}, 318.21 \mathrm{~g} \mathrm{~mol}^{-1}\right)$ calc. (found): C 15.10 (15.56), H 3.17 (3.24), N 61.62 (59.96)\%. IS: $5 \mathrm{~J}$ $(<100 \mu \mathrm{m})$. FS: $96 \mathrm{~N}(<100 \mu \mathrm{m})$. ESD $(<100 \mu \mathrm{m})$ : $0.5 \mathrm{~J}$.

Diguanidinium bis(1-oxidotetrazolyl)furazane (19). $3.1 \mathrm{~g}$ (10 mmol) of 11 was dissolved in $20 \mathrm{~mL}$ of $2 \mathrm{M}$ hydrochloric acid. The solution was extracted with $5 \times 30 \mathrm{~mL}$ of diethyl ether and the solvent was concentrated under reduced pressure. The residue was dissolved in $5 \mathrm{~mL}$ of water. 1.1 eq. of a solution of guanidinium carbonate in water was added under vigorous stirring. The solution was stirred for additional $30 \mathrm{~min}$, the solvent was then removed under reduced pressure and the precipitate was filtered off. The crude product was recrystallized from methanol,
$3.4 \mathrm{~g}$ of 19 was obtained as pale yellow crystal rods. DSC $\left(5{ }^{\circ} \mathrm{C} \min ^{-1}\right.$ ): 124 (mp.), 264 (dec.) ${ }^{\circ} \mathrm{C}$. IR (ATR, $25{ }^{\circ} \mathrm{C}$ ), $\tilde{\nu}$ (rel. int.): 3360 (s), 3206 (m), 3119 (s), 2813 (w), 1691 (w), 1656 (vs), 1591 (m), 1582 (m), 1469 (s), 1432 (w), 1404 (s), 1363 (m), 1291 (s), 1237 (s), 1140 (m), 1126 (m), 1040 (m), 1001 (m), 987 (s), 899 (m), $882(\mathrm{~m}), 770(\mathrm{w}), 750(\mathrm{w}), 696(\mathrm{w}) \mathrm{cm}^{-1}$. Raman (1064 nm, 400 $\mathrm{mW}, 25{ }^{\circ} \mathrm{C}$ ), $\tilde{\nu}$ (rel. int.): 3370 (2), 3229 (9), 1597 (9), 1578 (100), 1470 (5), 1368 (19), 1243 (9), 1180 (16), 1151 (6), 1128 (4), 1099 (7), 1010 (24), 906 (5), 777 (6), 752 (2), 542 (6), 462 (10), 293 (6), 136 (2), 106 (2) $\mathrm{cm}^{-1} .{ }^{1} \mathrm{H}$ NMR (270 MHz, DMSO- $\left.d_{6}, 25{ }^{\circ} \mathrm{C}\right), \delta: 6.63 \mathrm{ppm}$. ${ }^{13} \mathrm{C}\left\{{ }^{1} \mathrm{H}\right\}$ NMR (270 MHz, DMSO- $d_{6}, 25{ }^{\circ} \mathrm{C}$ ), $\delta: 158.1,144.2,132.9$ ppm. EA $\left(\mathrm{C}_{6} \mathrm{H}_{12} \mathrm{~N}_{16} \mathrm{O}_{3}, 356.27 \mathrm{~g} \mathrm{~mol}^{-1}\right)$ calc. (found): $\mathrm{C} 20.23$ (19.56), H 3.40 (3.63), N 62.90 (59.68)\%. IS: > $40 \mathrm{~J}(<100 \mu \mathrm{m})$. FS: $>360 \mathrm{~N}(<100 \mu \mathrm{m})$. ESD $(<100 \mu \mathrm{m}): 1.5 \mathrm{~J}$.

Diguanidinium bis(1-oxidotetrazolyl)furoxane (20). $1.7 \mathrm{~g}$ of $12(5.1 \mathrm{mmol})$ was dissolved in $20 \mathrm{~mL}$ of $2 \mathrm{M}$ hydrochloric acid and extracted four-times with $20 \mathrm{~mL}$ of diethyl ether. The solvent was removed under reduced pressure and the residue was dissolved in a few milliliters of water. Guanidinium carbonate $(0.9 \mathrm{~g}, 5.2 \mathrm{mmol})$ was added and the solution was heated while stirring. After filtration the mixture was cooled down to ambient temperature and 20 precipitated to give $1.8 \mathrm{~g}$ (4.8 mmol, 96\%) of colorless, crystalline blocks. DSC $\left(5{ }^{\circ} \mathrm{C}\right.$ $\min ^{-1}$ ): $197{ }^{\circ} \mathrm{C}$ (dec.). IR (ATR, $25^{\circ} \mathrm{C}$ ), $\tilde{\nu}$ (rel. int.): 3428 (s), 3342 (s), 3161 (s), 2793 (m), 2202 (w), 1999 (w), 1640 (vs), 1590 (s), 1553 (s), 1458 (m), 1423 (s), 1400 (m), 1335 (s), 1303 (s), 1243 (s), 1226 (s), 1180 (s), 1134 (m), 1106 (m), 1089 (m), 1026 (m), 1010 (m), 986 (s), 964 (s), 846 (w), 818 (s), 763 (s), 735 (s), 726 (s), 700 (m), $692(\mathrm{~m}) \mathrm{cm}^{-1}$. Raman (1064 nm, $\left.400 \mathrm{~mW}, 25{ }^{\circ} \mathrm{C}\right), \tilde{\nu}$ (rel. int.): 3267 (2), 1623 (42), 1594 (100), 1558 (40), 1460 (22), 1434 (12), 1338 (3), 1307 (27), 1234 (9), 1210 (64), 1183 (7), 1136 (15), 1109 (8), 1092 (5), 1028 (7), 1009 (69), 989 (18), 967 (3), 823 (8), 761 (12), 729 (8), 704 (9), 592 (4), 564 (11), 529 (14), 494 (11), 448 (14), 421 (14), 368 (23), 286 (7), 230 (26), 163 (26) cm $\mathrm{cm}^{-1}$. ${ }^{1} \mathrm{H}$ NMR (270 MHz, DMSO- $\left.d_{6}, 25{ }^{\circ} \mathrm{C}\right), \delta: 6.99 \mathrm{ppm} .{ }^{13} \mathrm{C}\left\{{ }^{1} \mathrm{H}\right\} \mathrm{NMR}$ $\left(270 \mathrm{MHz}, \mathrm{DMSO}-d_{6}, 25{ }^{\circ} \mathrm{C}\right), \delta: 158.5,146.9,133.8,130.9,105.9$ ppm. MS (FAB $\left.{ }^{+}\right): 60.1\left[\mathrm{CH}_{6} \mathrm{~N}_{3}^{+}\right], 373.1\left[\mathrm{M}+\mathrm{H}^{+}\right],\left(\mathrm{FAB}^{-}\right): 253.1$ $\left[\mathrm{C}_{4} \mathrm{HN}_{10} \mathrm{O}_{4}{ }^{-}\right]$. EA $\left(\mathrm{C}_{6} \mathrm{H}_{12} \mathrm{~N}_{16} \mathrm{O}_{4}, 372.26 \mathrm{~g} \mathrm{~mol}^{-1}\right)$ calc. (found): C 19.36 (19.74), H 3.25 (3.22), N 60.20 (59.93)\%. IS: 30 J (100-500 $\mu \mathrm{m})$. FS: $360 \mathrm{~N}(100-500 \mu \mathrm{m})$. ESD $(<100 \mu \mathrm{m}): 1.5 \mathrm{~J}$.

Disilver bis(1-oxidotetrazolyl)furoxane (21). $0.5 \mathrm{~g}$ of 11 (1.5 mmol) was dissolved in $20 \mathrm{~mL}$ of water and an aqueous solution of silver nitrate $(0.5 \mathrm{~g}, 3.0 \mathrm{mmol})$ was added, the silver salt precipitated immediately. After stirring and heating until boiling for a short time, the colorless solid was filtered off and air dried to give $0.7 \mathrm{~g}$ (1.4 mmol, 90\%) of $\mathrm{Ag}_{2}$ BOTFOX as a monohydrate. DSC $\left(5{ }^{\circ} \mathrm{C} \mathrm{min}{ }^{-1}\right): 221{ }^{\circ} \mathrm{C}$ (dec.). IR (ATR, $25{ }^{\circ} \mathrm{C}$ ), $\tilde{\nu}$ (rel. int.): 3365 (w), 3155 (w), 1628 (s), 1584 (s), 1462 (s), 1432 (s), 1397 (s), 1372 (m), 1302 (m), 1231 (vs), 1185 (m), 1092 (w), 1027 (w), 990 (m), 967 (s), 818 (s), 765 (s), 747 (m), 726 (m), 696 (m), $677(\mathrm{~m}) \mathrm{cm}^{-1} \cdot{ }^{13} \mathrm{C}\left\{{ }^{1} \mathrm{H}\right\}$ NMR (270 MHz, DMSO- $\left.d_{6}, 25{ }^{\circ} \mathrm{C}\right), \delta: 146.2,133.2,130.4,105.4$ ppm. MS (DEI $\left.{ }^{+}\right): 107.0\left[\mathrm{Ag}^{+}\right] . \mathrm{EA}\left(\mathrm{Ag}_{2} \mathrm{C}_{4} \mathrm{H}_{2} \mathrm{~N}_{10} \mathrm{O}_{5}, 485.86 \mathrm{~g} \mathrm{~mol}^{-1}\right)$ calc. (found): C 9.89 (10.09), H 0.41 (0.41), N 28.83 (28.47)\%. IS: 3 J $(<100 \mu \mathrm{m})$. FS: $16 \mathrm{~N}(<100 \mu \mathrm{m})$.

Diaminouronium bis(1-oxidotetrazolyl)furoxane dihydrate (22). $1.7 \mathrm{~g}$ of $12(5 \mathrm{mmol})$ was dissolved in $20 \mathrm{~mL}$ of $2 \mathrm{M}$ 
hydrochloric acid and extracted four-times with $20 \mathrm{~mL}$ of diethyl ether. The solvent was removed under reduced pressure and the residue was dissolved in a few milliliters of water. Diaminourea $(0.9 \mathrm{~g}, 10 \mathrm{mmol})$ was added and the solution was heated while stirring. After filtration the mixture was cooled down to ambient temperature and 22 precipitated as a colorless solid to give $1.8 \mathrm{~g}(4.8 \mathrm{mmol}, 96 \%)$ yield. DSC $\left(5{ }^{\circ} \mathrm{C} \mathrm{min}^{-1}\right)$ : $156{ }^{\circ} \mathrm{C}$ (dec.). IR (ATR, $25{ }^{\circ} \mathrm{C}$ ), $\tilde{\nu}$ (rel. int.): 3288 (w), 2964 (m), 2683 (m), 2133 (w), 1693 (m), 1618 (s), 1575 (s), 1557 (s), 1454 (s), 1427 (m), 1396 (m), 1377 (m), 1297 (m), 1233 (vs), 1180 (m), 1106 (w), 1014 (w), 990 (m), 965 (s), 826 (s), 750 (s), 734 (m), 678 (m) $\mathrm{cm}^{-1}$. Raman (1064 nm, $\left.400 \mathrm{~mW}, 25{ }^{\circ} \mathrm{C}\right), \tilde{\nu}$ (rel. int.): 1618 (20), 1586 (100), 1557 (20), 1453 (2), 1400 (11), 1298 (6), 1248 (9), 1209 (33), 1180 (5), 1145 (8), 1104 (5), 1016 (6), 993 (19), 830 (7), 769 (7), 736 (3), 711 (3), 691 (3), 591 (2), 502 (8), 453 (8), 407 (3), 670 (3), 242 (6), 154 (31), $102(47) \mathrm{cm}^{-1} .{ }^{1} \mathrm{H}$ NMR $(270 \mathrm{MHz}$, DMSO- $\left.d_{6}, 25{ }^{\circ} \mathrm{C}\right), \delta: 6.36$ ppm. ${ }^{13} \mathrm{C}\left\{{ }^{1} \mathrm{H}\right\}$ NMR (270 MHz, DMSO$\left.d_{6}, 25{ }^{\circ} \mathrm{C}\right), \delta: 158.4,145.6,135.1,132.5,105.0 . \mathrm{MS}\left(\mathrm{FAB}^{-}\right): 253.1$ $\left[\mathrm{C}_{4} \mathrm{HN}_{10} \mathrm{O}_{4}{ }^{-}\right]$, EA $\left(\mathrm{C}_{5} \mathrm{H}_{12} \mathrm{~N}_{14} \mathrm{O}_{7}, 380.24 \mathrm{~g} \mathrm{~mol}^{-1}\right)$ calc. (found): C 15.79 (16.23), H 3.18 (2.99), N 51.57 (51.47)\%. IS: $40 \mathrm{~J}(<100 \mu \mathrm{m})$. FS: $216 \mathrm{~N}(<100 \mu \mathrm{m})$. ESD $(<100 \mu \mathrm{m}): 1.5 \mathrm{~J}$.

Di(aminoguanidinium) bis(1-oxidotetrazolyl)furoxane (23). $1.7 \mathrm{~g}$ of $\mathbf{1 1}$ ( $5 \mathrm{mmol}$ ) was dissolved in $20 \mathrm{~mL}$ of $2 \mathrm{M}$ hydrochloric acid and extracted four-times with $20 \mathrm{~mL}$ of diethyl ether. The solvent was removed under reduced pressure and the residue was dissolved in a few milliliters of water. Aminoguanidinium bicarbonate $(1.4 \mathrm{~g}, 10 \mathrm{mmol}$ ) was added and the solution was heated while stirring. After filtration the mixture was cooled down to ambient temperature and 23 crystallized to give $1.9 \mathrm{~g}$ (4.7 mmol, 94\%) of colorless blocks. DSC $\left(5{ }^{\circ} \mathrm{C} \mathrm{min}^{-1}\right): 165{ }^{\circ} \mathrm{C}$ (dec.). IR (ATR, $25^{\circ} \mathrm{C}$ ), $\tilde{\nu}$ (rel. int.): 3424 (w), 3359 (m), 3303 (m), 3241 (m), 3101 (w), 1668 (vs), 1620 (s), 1585 (m), 1560 (s), 1455 (m), $1428(\mathrm{~m}), 1400(\mathrm{~m}), 1363(\mathrm{~m}), 1301(\mathrm{~m}), 1238$ (s), 1227 (s), 1193 (m), 1168 (m), 1095 (m), 1077 (m), 1056 (m), 1024 (w), 1009 (w), $990(\mathrm{~m}), 961$ (s), 910 (s), 823 (s), $771(\mathrm{~m}), 758$ (s), $732(\mathrm{~m})$, $710(\mathrm{~m}) \mathrm{cm}^{-1}$. Raman (1064 nm, $\left.400 \mathrm{~mW}, 25{ }^{\circ} \mathrm{C}\right), \tilde{\nu}$ (rel. int.): 3363 (6), 3263 (5), 1622 (31), 1588 (100), 1562 (30), 1456 (9), 1430 (6), 1397 (7), 1365 (5), 1303 (15), 1215 (69), 1170 (10), 1138 (14), 1107 (10), 1025 (6), 1011 (5), 992 (33), 966 (14), 824 (13), 773 (8), 752 (9), 735 (5), 711 (3), 687 (2), 624 (4), 591 (4), 557 (10), 501 (16), 460 (11), 434 (6), 405 (2), 375 (12), 342 (3), 285 (3), 260 (6), 231 (20), 155 (49), 138 (64), 127 (60), 100 (77), 89 (91) cm $\mathrm{cm}^{-1}$. ${ }^{1} \mathrm{H}$ NMR (270 MHz, DMSO- $\left.d_{6}, 25{ }^{\circ} \mathrm{C}\right), \delta: 8.70,7.26,6.90,4.51$ ppm. ${ }^{13} \mathrm{C}\left\{{ }^{1} \mathrm{H}\right\}$ NMR $\left(270 \mathrm{MHz}\right.$, DMSO- $\left.d_{6}, 25{ }^{\circ} \mathrm{C}\right), \delta: 159.4,147.0$, 133.8, 130.9, 106.0 ppm. $\mathrm{MS}\left(\mathrm{FAB}^{+}\right): 75.1\left[\mathrm{CH}_{7} \mathrm{~N}_{4}{ }^{+}\right], 403.2$ $\left[\mathrm{M}+\mathrm{H}^{+}\right],\left(\mathrm{FAB}^{-}\right): 253.1\left[\mathrm{C}_{4} \mathrm{HN}_{10} \mathrm{O}_{4}{ }^{-}\right]$. EA $\left(\mathrm{C}_{6} \mathrm{H}_{14} \mathrm{~N}_{18} \mathrm{O}_{4}\right.$, $402.29 \mathrm{~g} \mathrm{~mol}^{-1}$ ) calc. (found): C 17.91 (18.17), H 3.51 (3.47), N 62.67 (61.54)\%. IS: $8 \mathrm{~J}(<100 \mu \mathrm{m})$. FS: $360 \mathrm{~N}(<100 \mu \mathrm{m})$.

\section{Acknowledgements}

Financial support of this work by the Ludwig-Maximilian University of Munich (LMU), the U.S. Army Research Laboratory (ARL) under grant no. W911NF-09-2-0018, the Armament Research, Development and Engineering Center (ARDEC) under grant no. W911NF-12-1-0467, and the Office of Naval Research (ONR) under grant nos. ONR.N00014-10-1-0535 and ONR.N00014-12-1-0538 is gratefully acknowledged. The authors acknowledge collaborations with Dr Mila Krupka (OZM Research, Czech Republic) in the development of new testing and evaluation methods for energetic materials and with Dr Muhamed Suceska (Brodarski Institute, Croatia) in the development of new computational codes to predict the detonation and propulsion parameters of novel explosives. We are indebted to and thank Drs Betsy M. Rice and Brad Forch (ARL, Aberdeen, Proving Ground, MD) for many inspired discussions. We also thank Mr Stefan Huber for sensitivity measurements.

\section{Notes and references}

1 G. A. Parker, G. Reddy and M. A. Major, Int. J. Toxicol., 2006, 25(5), 373-378.

2 N. Fischer, D. Fischer, T. M. Klapötke, D. G. Piercey and J. Stierstorfer, J. Mater. Chem., 2012, 22, 20418-20422.

3 D. Fischer, T. M. Klapötke, D. G. Piercey and J. Stierstorfer, Chem. - Eur. J., 2013, 19, 4602-4613.

4 M. Göbel, K. Karaghiosoff, T. M. Klapötke, D. G. Piercey and J. Stierstorfer, J. Am. Chem. Soc., 2010, 132, 17216-17226.

5 T. I. Godovikova, S. K. Vorontsova, L. D. Konyushkin, S. I. Firgang and O. A. Rakitin, Russ. Chem. Bull., 2010, 58, 406-409.

6 H. Huang, Z. Zhou, L. Liang, J. Song, K. Wang, D. Cao, C. Bian, W. Sun and M. Xue, Z. Anorg. Allg. Chem., 2012, 638, 392.

7 C. Grundmann, Chem. Ber., 1964, 97, 575-878.

8 C. Grundmann, G. W. Nickel and R. K. Bansal, Justus Liebigs Ann. Chem., 1975, 6, 1029-1050.

9 S. M. Aldoshin, Z. G. Aliev, A. A. Astratev, T. K. Goncharov, D. V. Dashko, Yu. M. Milekhin, A. I. Stepanow and N. I. Shishow, Zh. Strukt. Khim., 2013, 54, 399 (J. Struct. Chem.).

10 H. Huang, Z. Zhou, L. Liang, J. Song, K. Wang, D. Cao, W. Sun, C. Bian and M. Xue, Chem. - Asian J., 2012, 7, 707.

11 D. Fischer, T. M. Klapötke and J. Stierstorfer, Chem. - Eur. J., 2013, 19, 4602.

12 (a) Test methods according to the UN Recommendations on the Transport of Dangerous Goods, Manual of Tests and Criteria, fourth revised edition, United Nations Publication, New York and Geneva 2003; (b) www.bam.de; (c) www. reichel-partner.de.

13 http://www.ozm.cz.

14 (a) M. Sućeska, Calculation of Detonation Parameters by EXPLO5 Computer Program, Mater. Sci. Forum, 2004, 465-466, 325; (b) M. Suceska, Calculation of the Detonation Properties of C-H-N-O Explosives, Propellants, Explos., Pyrotech., 1991, 16, 197.

15 C. Xue, J. Sun, B. Kang, Y. Liu, X. Liu, G. Song and Q. Xue, Propellants, Explos., Pyrotech., 2010, 35, 333-338.

16 R. Mayer, J. Köhler and A. Homburg, Explosives, Wiley VCH, Weinheim, 5th edn, 2002.

17 P. Hakey, W. Ouellette, J. Zubieta and T. Korter, Acta Crystallogr., Sect. E: Struct. Rep. Online, 2008, E64, 1428.

18 C. S. Choi and E. Prince, Acta Crystallogr., Sect. B: Struct. Crystallogr. Cryst. Chem., 1972, 28, 2857. 